\title{
CHANGES OF VIEWPOINTS IN INDONESIAN-ENGLISH TRANSLATION
}

\author{
Made Susini \\ Universitas Warmadewa \\ madesusini@yahoo.com \\ Nyoman Sujaya \\ Universitas Warmadewa \\ nyomansujaya753@gmail.com
}

\begin{abstract}
This study concerns with translation which involves languages that have different linguistic and cultural systems. When a source and target language do not have the same system of language and culture, to some extent, equivalence cannot be directly achieved. By deploying Vinay \& Darbelnet's Modulation (1995) and House's translation equivalence (2015), this study is to reveal the changes of point of view the translators did in translating texts from Indonesian into English. The data sources of this present study include Indonesian novels and short stories loaded with culture and their English translations. The analysis revealed that to create adequate target texts, the translators changed their points of view through some conditions. The changes include: a) negation of opposite; b) part for the whole; c) abstract for concrete; d) cause for effect; e) active for passive; f) space for time; g) change of symbols; and h) intervals and limits. Changing point of view becomes cultural bridge in the translation which involves languages with different culture.
\end{abstract}

Keywords: direct equivalent; modulation; point of view

\section{INTRODUCTION}

Translation deals with texts transferred from one language into another language. In its process, some factors take part. One of them is how the text is realized in target language (TL) and what form is chosen as the target text (TT) is very much influenced by the translator decision. When a translator decides to choose a certain target form, some contextual factors have been put into considerations. Every language has its own system and culture. This means that how meaning is realized as the TL and what forms are chosen as target texts will be very much influenced by the culture of the language under study (Xia, 2015).

This present study concerns with the translation from Indonesian into English. Indonesian and English are languages which have different culture that Indonesian and English people will view world differently. When a text of Indonesian is translated into English, the source meaning may not have direct equivalent in target language, or it may have different way in realizing meaning. To bridge the cultural difference between Indonesian and English, a translator has to be capable of choosing the translation procedures appropriate for overcoming the problem. There are some classifications of translation procedures proposed by the experts (Malone, 1988; Molina \& and Albir, 2002; Newmark, 1988; Vinay \& \& Darbelnet, 1995). One of the translation procedures which is applicable to overcome cultural differences in translation is Modulation.

Modulation refers to a change of point of view or a change of perspective when rendering a source text (ST) into target language (Vinay \& \& Darbelnet, 1995: 245-255). There some types of modulation proposed, among those are: a) negation of opposite; b) part for the whole; c) abstract for concrete; d) cause for effect; e) active for passive; f) space for time; g) change of symbols; h) intervals and limits; i) partanother part; and $j$ ) reversal of terms . 
Changing point of view is one of the procedures a translator could choose to achieve target texts which are equivalent viewed from semantic, pragmatic, and textual aspects of meaning (House, 2015). In translating texts, translation equivalence and translation procedure are inter-connected and become major concepts in translation. Considering this, translation procedure and translation equivalence have become researchers' interests. There have been a number of research on this topics conducted. Researches on translation equivalence were conducted by (Akbari, 2012) and on translation procedures by (Amjad, 2013; Huang \& \& Li, 2015; Kalani, N. \& Sharif, 2017; Naghdi \& \& Eslamieh, 2020; Xia, 2015); Huang, J. \& Li, Y. (2015); Xia (2015; Kalani, N. \& Sharif, F.D (2017); and Naghdi \& Eslamieh, (2020). Some also worked on modulation, such as Delzendehrooy who carried out modulation in the translation of poetry (Delzendehrooy \& \& Karimnia, 2013). The researches conducted show that translation procedure was investigated from different perspectives. Applying the concept of modulation as a change of view by Vinay \& Darbelnet (1995), this research is to examine the change of point of view in the translation of Indonesian texts into English.

\section{METHOD}

The data of this present study were taken from Indonesian novels and short stories and their English translations. The novels used are entitled Sukreni Gadis Bali (Tisna, 2013)as SL and The Rape of Sukreni (Quinn, 2012) as TL, Ni Tantri (Gianyar, 1999) as SL and Ni Tantri (Puspani, 2008) as TL, Sitti Nurbaya (Rusli, 1922) as SL and Sitti Nurbaya (Fowler, 2009) as TL, and Belenggu (Pane, 2000) as SL and Shackles (McGlynn, 1988) as TL. These Indonesian novels and short stories were used as data sources since they contain words and expressions loaded with Indonesian culture.

Considering that his research worked on modulation as the procedure of changing point of view in translation, the data selected were in the forms of words and clauses. The data were collected by applying observation method through reading and note-taking technique. The analysis were carried out by referring to the concept of modulation by Vinay \& Darbelnet
(1995). The units found in the ST and TT were compared to identify whether the change of point of view occurred in the translation under study. By comparing the forms of the ST and TT, the type of modulation found in each instance was identified. Comparison method was also applied to find out whether the ST was adequately translated into TL by referring to the translation equivalence by House (2015).

\section{DISCUSSION}

The analysis reveals that some types of modulation occur in the Indonesian-English translation. The translators of the novels under study change his/her point of view to achieve equivalence. When he/she turns his/her point of view, some results are found. ST which is specific, as the example, is translated into the one which is more generic. The types of modulation found out include: a) negation of opposite; b) part for the whole; c) abstract for concrete; d) cause for effect; e) active for passive; f) space for time; g) change of symbols; and h) intervals and limits.

\section{a) Negation of Opposite}

This type of modulation refers to the translation procedure by negating the opposite of the ST words or expressions.

(1) ST: "Jangan mendekat ke unggukan kelapa itu! Teriak seorang penjaga kepada seorang perempuan yang mendukung bakul di dekat unggukan kelapa (Tisna, 2013: 17).

TT: A woman with a basket on her head could be seen moving towards one of the piles. "Keep away from there!" one of the supervisors shouted (Quinn, 2012: 15).

(2) ST: Tidak jarang I Mujana, mandor yang muda itu, marah-marah, jika ia melihat perempuan datang dengan maksud jahat itu (Tisna, 2013: 15).

TT: Occasionally the young foreman, I Mujana could not help but lose his temper when seeing these cunning women in the grove (Quinn, 2012: 15).

(3) ST: "Hei!" teriak mandor penjaga itu dengan keras suaranya, "pergi, jangan dekat orang mengupas." (Tisna, 2013: 18).

TT: Get out of there!" I Mujana yelled. "Stay away from those men!" (Quinn, 2012: 16). 


\section{CHANGES OF VIEWPOINTS IN INDONESIAN-ENGLISH TRANSLATION}

To achieve equivalence in TL and to create an adequate translation, the Indonesian text could be rendered into English by changing point of view. To translate the data (1), (2), and (3), the source units are not translated directly. The equivalence is achieved by negating the opposite of the source units. Jangan mendekat meaning 'keep away' in (1), Tidak jarang meaning 'often' in (2), and Jangan dekat meaning 'keep away' are rendered into English through the following process.

Table 1. Negation of Opposite

\begin{tabular}{|c|c|c|c|c|c|}
\hline No & Data & Meaning & Opposite & $\begin{array}{c}\text { Negation of } \\
\text { opposite }\end{array}$ & Equivalent \\
\hline (1) & Jangan mendekat & 'keep away' & don't keep away & keep away & Keep away \\
\hline (2) & Tidak jarang & often/ occasionally & not often & often & Occasionally \\
\hline (3) & Jangan dekat & 'keep away' & don't keep away & keep away & Stay away \\
\hline
\end{tabular}

Form semantic meaning, STs and TTs are equivalent since they express the same meaning. For instance, in datum (1) the meaning conveyed by the ST and TT is asking someone to keep away. When they are viewed from their pragmatic meanings, they are pragmatically equivalent. To express that meaning, it is acceptable for the speakers of Indonesian to use negative imperative represented by Jangan mendekat and for the speakers of English to use positive imperative represented by Keep away.

\section{b) Part for Whole}

Part for whole type refers to the procedure by using more specific words or expressions for more general words or expressions, and viceversa.

(4) ST: Ni Tantri sangat terharu. Tanpa terasa air mata harunya jatuh berlinang. Kemudian iapun merasa tidak tahan lagi, lalu memeluk $\mathrm{Ni}$ Kecubung dengan hangat. Setelah itu bersimpuh di depan Ni Lasmi (Gianyar, 1999: 32)

TT: Ni Kecubung was very pleased. She did not realize her tears felt on her face. She could not resist her feeling then she hugged Ni Kecubung warmly. Then she sat on the ground in front of $\mathrm{Ni}$ Lasmi (Puspani, 2008).

(5) ST: Ni Lasmi dan Ni kecubung, istri dan putri I Made Mandra menyambut kepulangannya itu dengan terharu dan bahagia. Mereka memeluk I Made Mandra dengan hangat.

"Dinda telah sangat cemas menantimu, Kanda...." (Gianyar, 1999: 28).

TT: Ni Lasmi dan Ni Kecubung, the wife and the daughter of I Made Mandra greeted him happily. They hugged him tenderly.

"I was so worried waiting for you...." (Puspani, 2008: 21).

(6) ST: "Lalu bagaimana?" desak Ni kecubung.

"Kala Danawa membawa saya ke gua tempat tinggalnya, tanpa memperdulikan tangisan saya. Rupanya ia bermaksud hendak memasak saya di dalam sebuah kuali besar!...." (Gianyar, 1999: 72)

TT: "What happened then?" urged Ni Kecubung.

"Kala Denawa took me to the cave he lived in, He innored as I was crying. It seemed he will cook me in a very big pot...." (Puspani, 2008: 57).

(7) ST: Dengan tangkas ia mengepit tubuh I Made Mandra, , dan dengan sebelah tangannya yang lain, ia berenang ke tepi sungai (Gianyar, 1999: 16).

TT: In a careful way she hold I Made Mandra's body, and she used her other hand swimming towards the edge of the river (Puspani, 2008: 10).

(8) ST: "Jangan-jangan ia tertidur, karena mengantuk; sebab tadi malam ia minta izin kepada ayahku, pergi menonton komidi kuda (Rusli, 1922: 3).

TT: "Let's hope he didn't doze off," the young man replied, seemingly irritated. "Last night he asked my father if he could go see the circus (Fowler, 2009: 2).

Some of the equivalence found are achieved by using more generic words. Since the meanings cannot be conveyed through direct translation, the translator changes his point of view. The item which is specific is turned into item which is more generic. In (4) 
bersimpuh is a term used to refer to one of the ways how the Balinese women usually sit when praying. In its TT it is translated by using a generic word sat on the ground which does not describe a specific way of sitting. Dinda in (5) refers to a specific term which refers to first person singular. In Indonesian language there are some choices of term can be used to refer to first person singular which depends on the communication situation of the text. In TT there is only one choice to translate dinda, that is by $I$. The use of more generic word is also found in (6). Kuali is one kind of pot used as cooker for the Indonesian people. In (7) mengepit is also one of the ways of holding something. It is by positioning something between the body and the arm. Holding as used in TT has no such specific meaning and hold is the generic word for mengepit. Datum (8) also shows the use of more general word by using the word the circus for more specific word komedi kuda.

Table 2. Part for Whole

\begin{tabular}{|c|c|c|c|}
\hline No & ST & Part & Whole \\
\hline (4) & Bersimpuh & $\begin{array}{l}\text { Bersimpuh, } \\
\text { berselonjor, } \\
\text { bersila, ... }\end{array}$ & Duduk 'sit' \\
\hline (5) & Dinda & $\begin{array}{l}\text { Dinda, kanda, } \\
\text { saya, aku, diriku, } \\
\text { hamba... }\end{array}$ & Saya 'I' \\
\hline (6) & Kuali & $\begin{array}{l}\text { Kuali, panci, } \\
\text { loyang, mangkok, } \\
\text {... }\end{array}$ & Wadah 'pot' \\
\hline (7) & Mengepit & $\begin{array}{l}\text { Mengepit, } \\
\text { menjingjing, } \\
\text { membawa... }\end{array}$ & $\begin{array}{l}\text { Memegang } \\
\text { 'hold' }\end{array}$ \\
\hline (8) & $\begin{array}{l}\text { Komidi } \\
\text { kuda }\end{array}$ & $\begin{array}{l}\text { Komidi kuda, } \\
\text { atraksi akrobat, } \\
\text { badut, sepeda, .. }\end{array}$ & $\begin{array}{l}\text { Sirkus } \\
\text { 'circus, }\end{array}$ \\
\hline
\end{tabular}

When the TT uses more general words, contextually, the original meaning of the words will change. In some cases, this is a kind of obligatory modulation since English has different culture and the speakers of English view world differently.

\section{c) Abstract for Concrete}

Some data show that the source units are expressed in abstract forms, i.e. they use figurative language to realize meanings. In its English translations, the translators change his point of view by rendering them by using nonfigurative language as found in the following data.
(9) ST: Karena itu sambil memberi recept, katanya dengan lemah lembut: "Tidak selamanya hari hujan, besok lusa akan panas juga."

Nyonya Eni berdiri, air mukanya riang gembira: "Maafkan saya, termenung. Patutlah tuan dokter menyindir." (Pane, 2000: 22).

TT: Handing the prescription slip to the woman, Sukartono reassured her. "Cheer up. It can't be that bad. The sun will rise tomorrow." (McGlynn, 1988: 8).

(10) ST: "Tentu tak dapat," jawab Samsu., "memang bagi seorang pegawai, hal yang sedemikian seperti kata pepatah: bagai bertemu buah si mala kamo ..."(Rusli, 2010).

TT: "You certainly couldn't," replied Samsu. Of course, for a civil servant, such issues remind us of the old saying, 'Damned if you do, damned if you don't ..." (Fowler, 2009: 34).

The expressions found in the SL text show figurative meanings that they are regarded as abstract expressions. The forms used are Tidak selamanya hari hujan in (9) and bagai bertemu buah si mala kamo in (10). When these expressions are translated directly, the result will be considered unidiomatic. So, these expressions are rendered into expressions which sounds concrete by using forms having nonfigurative meanings. When a message is conveyed non-figuratively, the information tends to be more direct. This is one of the effects of this procedure. The following shows how the $\mathrm{ST}$ and TT are put in comparison.

Table 3. Abstract for Concrete

\begin{tabular}{lllll}
\hline No & $\begin{array}{c}\text { Figurative } \\
\text { ST }\end{array}$ & $\begin{array}{l}\text { Literal } \\
\text { translation }\end{array}$ & $\begin{array}{l}\text { Idiomatic } \\
\text { translation }\end{array}$ & $\begin{array}{c}\text { TT } \\
\text { forms }\end{array}$ \\
\hline (9) & $\begin{array}{l}\text { Tidak } \\
\text { selamanya } \\
\text { hari hujan }\end{array}$ & $\begin{array}{l}\text { Not } \\
\text { everyday } \\
\text { the day } \\
\text { rains. }\end{array}$ & $\begin{array}{l}\text { Don't be } \\
\text { sad. }\end{array}$ & $\begin{array}{l}\text { Cheer } \\
\text { up. }\end{array}$ \\
& & As meeting & He is \\
(10) & $\begin{array}{l}\text { Bagai } \\
\text { bertenu } \\
\text { buah si } \\
\text { mala kamo }\end{array}$ & kamo. & $\begin{array}{l}\text { Damned } \\
\text { damned } \\
\text { whatever } \\
\text { he does. }\end{array}$ & $\begin{array}{l}\text { if you } \\
\text { domned } \\
\text { damnou } \\
\text { if you } \\
\text { don't. }\end{array}$ \\
\hline
\end{tabular}

\section{d) Cause for Effect}

One of the translator's considerations in choosing the TT forms is whether he or she wants to emphasize what someone does or what the result of the action he does. The following 
data concern with the change of point of view of cause for effect.

(11) ST: Baginya Songket sudah keblinger, mencampuradukkan modern dengan tradisi. "Jika ingin jadi tokoh pembaru, janganlah dengan jalan menghasut masyarakat," tuduh Endek (Soethama, 2006: 135).

TT: For him it was very wrong to mix the modern and the traditional. "If you become a reformer, okay, don't become a rabble rouser, he said accusingly (Cork, 2008: 48).

(12) ST: "Dimana orang mengamuk itu? tanya Nurbaya.

"Aku pun tak tahu," jawab Samsu (Rusli, 2010: 29)

TT: "Where was the attack" asked Nurbaya."I don't know, “ replied Samsu (Fowler, 2009: 23).

Modulation of cause for effect can be found in (11) and (12). The SL texts show the cause and the TL texts show the action done. The translator changes his point of view which goes from the cause to the effect.

Table 4. Cause for Effect

\begin{tabular}{|c|c|c|c|}
\hline No & ST & $\begin{array}{c}\text { ST } \\
\text { meaning }\end{array}$ & The effect \\
\hline (11) & $\begin{array}{l}\text { (Kamu) } \\
\text { menghasut } \\
\text { masyarakat }\end{array}$ & $\begin{array}{l}\text { (You) make } \\
\text { trouble }\end{array}$ & $\begin{array}{l}\text { He is a } \\
\text { troublemaker/ } \\
\text { rabble rouser }\end{array}$ \\
\hline (12) & $\begin{array}{l}\text { Orang } \\
\text { mengamuk }\end{array}$ & $\begin{array}{l}\text { Someone is } \\
\text { attacking } \\
\text { other } \\
\text { people }\end{array}$ & $\begin{array}{l}\text { There is an } \\
\text { attack }\end{array}$ \\
\hline
\end{tabular}

These translations show that the writers of the SL text are more concentrate on the action, i.e. menghasut meaning "make trouble" in (11) and mengamuk meaning 'doing an attack', while the translators on the result, i.e. a rabble rouser in (11) and an attack in (12). Semantically, the two translations are equivalent, but in terms of their pragmatic meaning, they have different effect to the readers.

\section{e) Active for Passive}

Changing the constructions in TL from active into passive or vice-versa is also a kind of modulation. The data found are as the followings.
(13) ST: Diberinya aku sebuah teropong genggam yang bisa aku pinjamkan pada turis-turis itu (Soethama, 2006: 65).

TT: He gave me a pair of binoculars for the tourists to borrow (Cork, 2008: 109).

(14) ST: Dijinjingnya lukisan itu turun dari bale dangin (Soethama, 2006: 150)

TT: Then he took his painting down from the bale dangin (Cork, 2008: 116).

(15) ST: Rapat keluarga kemudian memutuskan akan diselenggarakan upacara mecaru yang besar (Soethama, 2006: 57)

TT: At the family meeting it was decided to perform a big macaru cleansing ceremony (Cork, 2008: 131).

The STs of (13) and (14) are in passive forms characterized by the verbs diberi in (13) and dijinjing (14), while the one of (15) is in active form characterized by the verb memutuskan. From semantic meaning perspective, a text which is realized in active or in passive construction will have the same meaning. Textually, the information conveyed is different since the element functioning as a theme is not the same. Theme is element which is considered more important or central in a discourse. So, in the data above the changes of theme occur, such as diberinya into he in (13). The information which is regarded as more important also changes. The ST writer gives more emphasize on the action diberinya, while the translator on the agent of the action represented by $h e$.

\section{f) Space for Time}

Space and time are terms used to function as Adverbial in a clause structure. Space deals with Adverbial of place and time with Adverbial of time. Space which is replaced by time, or vice-versa, is also found in IndonesianEnglish translation as seen in the following data.

(16) ST: Setelah sejurus lamanya berbendi, berkatalah anak laki-laki tadi, "Nur, belum kauceritakan kepadaku, apa sebabnya mukamu merah." (Rusli, 2010: 6).

TT: In the chart, Sam pursued his earlier query.

"Nur, you haven.t told me why your face is red." (Fowler, 2009: 4) 
In this translation the ST contains Adverbial of time represented by setelah sejurus lamanya berbendi. In TL, this Adverbial of time is rendered into English by using Adverbial of place in the chart. This translation shows that the change of point of view concerns with the change of replacing time by space. By the use of Adverbial in the text, the ST writer informs what happened after some minutes in the chart, while the translator informs what happened in the chart.

\section{g) Change of Symbol}

Indonesian and English, to some extent, do not share the same culture. When the translation from Indonesian into English concerns with texts which are related to culture, procedure by changing symbol is commonly found.

(17) ST: Tubuhnya sangat tinggi besar, ditumbuhi oleh bulu-bulu yang kaku dan kasar pula, seperti ijuk; ... (Gianyar, 1999: 7).

TT: He has a huge figure of which was full of rough and thick hair all over his body like nails, .... (Puspani, 2008: 1).

(18) ST: “... tetapi aku lebih suka naik bendi dari pada berjalan kaki, pulang ke rumah, sebab aku amat lelah rasanya dan hari amat panas. Lihatlah mukamu, telah merah sebagai jambu air, kena panas matahari!" (Rusli, 2010: 3)

TT: ... But I'd rather take a buggy than walk because now I'm really tired and it's so hot. Look at your face, as red as an apple under all this sun!" (Fowler, 2009: $3)$.

(19) ST: Kira-kira pukul satu siang, kelihatan dua orang anak muda, bernaung di bawah pohon ketapang yang rindang, di muka sekolah Belanda Pasar Ambacang di Padang, ... (Rusli, 2010: 1).

TT: Around one in the afternoon, in front of the Dutch school in Padang's Ambacang market district, a young man and woman stood in the shade of a dense almond tree (Fowler, 2009: 1).

(20) ST: Dahulu setiap hari engkau datang kemari, makan dan minum di sini dan kadang-kadang tidur pula di sini. Barang apa yang kau kehendaki, engkau minta atau kau ambil sendiri. Rumah ini kau pandang sebagai rumahmu sendiri. Akan tetapi, sekarang ini, jangankan tidur di sini, menjaga kami, datang melihat kami kemari sekali sejumat pun tidak (Rusli, 2010: 16).

TT: Before, you used to come almost every day to eat here and sometimes even to sleep. Whatever you needed, you only had to ask and I'd go get it myself. You considered this house your very own. But, now, not only do you not sleep here and watch over us, you don't even drop by once a week (Fowler, 2009: 11-12).

To convey the same meaning to the TL, the translator could make adjustment by changing the symbol. To create the same nuance of meaning as described by ijuk in (17), the symbol used can be replaced by the one usually used in the TL. In this example nails is used. The decision to use nails is because of the similar characteristics of the two words. They have characteristics of being sticky. The similar characteristics of the source and the target items are presented in the following table.

Table 5. Change of Symbol

\begin{tabular}{llll}
\hline No & \multicolumn{1}{c}{ ST } & \multicolumn{1}{c}{ TT } & \multicolumn{1}{c}{$\begin{array}{c}\text { Similar } \\
\text { characteristics }\end{array}$} \\
\hline (17) & Ijuk & nails & being sticky \\
\hline$(18)$ & Jambu air & an apple & being fresh \\
\hline$(19)$ & $\begin{array}{l}\text { Pohon } \\
\text { ketapang }\end{array}$ & $\begin{array}{l}\text { almond } \\
\text { tree }\end{array}$ & having shady \\
leaves
\end{tabular}

The similar characteristics of the ST and TT as presented in the table above become the translators' considerations in using an apple in (18), almond tree in (19), and a week in (20) as the equivalents in English.

\section{h) Intervals and Limits}

The following datum indicates that there is a modulation type of interval and limit. between limit and interval represented by adverb of time setahun lalu and after only one year.

(21) ST: Setahun lalu ia bahkan sudah membeli mobil Suzuki Carry (Soethama, 2006: 153).

TT: After only one year he'd bought a Suzuki Carry (Cork, 2008: 119).

In this translation the ST contains Adverbial of time represented by setahun lalu meaning 'a year ago'. This phrase is used to express time limit. The TT also contains 


\section{CHANGES OF VIEWPOINTS IN INDONESIAN-ENGLISH TRANSLATION}

Adverbial of time realized by after only one year, but this phrase is showing time interval. This translation implies that the ST writer gives more focus on the When, while the TT writer on the After How long time.

\section{CONCLUSION}

Procedure by changing point of view could be applicable to solve the cultural problems in the translations from Indonesian into English. Semantically, the changes of point of view, in general, do not result in the change of meaning. The meaning could be kept constant in TL. In some cases, this procedure results in a change of pragmatic and textual meaning.

\section{REFERENCES}

Akbari. (2012). Structural Shifts in Translation of Children's Literature. International Journal of Linguistics, 4(2). https://dx.doi.org/10.5296/ijl.v4i2.1911

Amjad, F. A. (2013). Problems and Strategies in English Translation of Quranic Divine Names. International Journal of Linguistics, $5(1)$. https://dx.doi.org/10.5296/ijl.v5il/3301

Cork, V. (2008). Ordeal by Fire. Arti Foundation.

Delzendehrooy, M., \& \& Karimnia, A. (2013). A comparative study of modulation in English translation of Khayyam's quatrains. Procedia-Social \& Behavioral Sciences 70, 28-40.

Fowler, G. A. (2009). Sitti Nurbaya. A Love Unrealized. The Lontar Foundation.

Gianyar, I. R. (1999). Ni Tantri. CV. Pioner Jaya.

House, J. (2015). Translation Quality Assessment. Routledge.

Huang, J., \& \& Li, Y. (2015). Strategies for Translating Household Appliance Instructions from Chinese to English. Theory and Practice in Language Studies, 5(12), 2522-2527. http://dx.doi.org/10.17507/tpls.0512.12

Kalani, N. \& Sharif, F. . (2017). English Translation of Iranian Local Cultural Patters of "Isfahan Nameh." International Journal of English Literature and Social Sciences (IJELS). https://dx.doi.org/10.22161/1 jels.2.6.21

Malone, J. L. (1988). The Science of Linguistics in the Art of Translation. State University of New York Pess.

McGlynn, J. H. (1988). Shackles. The Lontar Foundation.

Molina, L., \& and Albir, A. H. (2002). Translation Technique Revisited: A Dynamic and Functionalist Approach. Jurnal Meta, XLVIII(4).

Naghdi, H., \& \& Eslamieh, R. (2020). Bakerian Non-equivalence Translation Strategies in Novel vs Short Story: the Case Study of Maldaus vs Landlady and Other Short Stories. Theory and Practice of Language Studies, 10(8), 886-897.

Newmark, P. (1988). A Text Book of TranslationNo Title. Prentice Hall.

Pane, A. (2000). Belenggu. PT Dian Rakyat.

Puspani, I. A. M. (2008). Ni Tantri. Udayana University Press.

Quinn, G. (2012). The Rape of Sukreni. The Lontar Foundation.

Rusli, M. (2010). Sitti Nurbaya. PT Balai Pustaka.

Soethama, G. A. (2006). Mandi Api: Kumpulan Cerita Pendek. buku arti.

Tisna, A. A. P. (2013). Sukreni Gadis Bali. PT. Balai Pustaka.

Vinay, J. P., \& \& Darbelnet, J. (1995). Comparative stylistics of French and English. A methodology for translation (J. C. Sager \& M. J. Hamel, Trans.). John Benjamins.

Xia, X. (2015). Meaning in Context and Nature of Translation. Theory and Practice in Language Studies, 5(3), 652-656. http://dx.doi.org/10.17507/tpls.0503.28 